Cellular Physiology
and Biochemistry and Biochemistry Published online: May 23, 2016

Accepted: April 27, 2016

This article is licensed under the Creative Commons Attribution-NonCommercial-NoDerivatives 4.0 International License (CC BY-NC-ND) (http://www.karger.com/Services/OpenAccessLicense). Usage and distribution for commercial purposes as well as any distribution of modified material requires written permission.

\title{
Anidulafungin-Induced Suicidal Erythrocyte Death
}

\author{
Thomas Peter Rosi Bissinger Guilai Liu Florian Lang \\ Department of Cardiology, Vascular Medicine and Physiology, University of Tuebingen, Tuebingen, \\ Germany
}

\section{Key Words}

Phosphatidylserine • Cell volume • Eryptosis $•$ SB203580 • zVAD • Calcium • Hemolysis

\begin{abstract}
Background/Aims: The novel antifungal drug Anidulafungin is used for the treatment of diverse fungal infections including candidiasis and aspergillosis. The traditional antifungal drug amphotericin B has previously been shown to trigger eryptosis, the suicidal death of erythrocytes characterized by cell shrinkage and cell membrane scrambling with phosphatidylserine translocation to the erythrocyte surface. Triggers of eryptosis include increase of cytosolic $\mathrm{Ca}^{2+}$ activity $\left(\left[\mathrm{Ca}^{2+}\right]_{i}\right)$, oxidative stress, ceramide, activated protein kinase $\mathrm{C}(\mathrm{PKC})$, casein kinase $1 \alpha$ or p38 kinase and activated caspases. Inhibitors of eryptosis include nitric oxide (NO). The present study explored, whether Anidulafungin induces eryptosis. Methods: Flow cytometry was employed to estimate phosphatidylserine abundance at the erythrocyte surface from annexin-V-binding, cell volume from forward scatter, $\left[\mathrm{Ca}^{2+}\right]_{i}$ from Fluo3-fluorescence, abundance of reactive oxygen species (ROS) from DCFDA dependent fluorescence, and ceramide abundance at the erythrocyte surface utilizing specific antibodies. Hemolysis was quantified by measuring haemoglobin concentration in the supernatant. Results: A 48 hours exposure of human erythrocytes to Anidulafungin $(1.5-6 \mu \mathrm{g} / \mathrm{ml})$ significantly increased hemolysis and the percentage of annexin-V-binding cells, and significantly decreased forward scatter. Anidulafungin $(6 \mu \mathrm{g} / \mathrm{ml})$ slightly, but significantly inceased Fluo3-fluorescence and the effect of Anidulafungin on annexin-V-binding was slightly, but significantly blunted by removal of extracellular $\mathrm{Ca}^{2+}$. The effect of Anidulafungin on annexin-V-binding was further significantly blunted by the p38 kinase inhibitor SB203580 (2 $\mu \mathrm{M})$ and NO donor nitroprusside $(1 \mu \mathrm{M})$. An increase of extracellular $\mathrm{K}^{+}$concentration significantly blunted the effect of Anidulafungin on cell volume but not on annexin- $V$-binding. Anidulafungin rather decreased DCFDA fluorescence and the effect of Anidulafungin on annexin-V-binding was not significantly blunted by the antioxidant $\mathrm{N}$-acetylcysteine $(1 \mathrm{mM})$. Moreover, the effect of Anidulafungin on annexin-V-binding was not paralleled by significant increase of ceramide abundance and was not significantly blunted by PKC inhibitor staurosporine $(1 \mu \mathrm{M})$, casein kinase $1 \alpha$ inhibitor D4476 $(10 \mu \mathrm{M})$ or pancaspase inhibitor ZVAD $(10 \mu \mathrm{M})$. Conclusions: Anidulafungin triggers hemolysis and eryptosis with cell shrinkage and phospholipid scrambling of the erythrocyte cell membrane, an effect in part due to $\mathrm{Ca}^{2+}$ entry and activation of p38 kinase.




\section{Cellular Physiology Cell Physiol Biochem 2016;38:2272-2284 and Biochemistry Published online: May 23, $2016 \quad \begin{aligned} & \text { DOI: 10.1159/000445582 } \\ & \begin{array}{l}\text { C } 2016 \text { The Author(s). Published by S. Karger AG, Basel } \\ \text { www.karger.com/cpb }\end{array}\end{aligned}$ \\ Peter/Bissinger/Liu/Lang: Anidulafungin-Induced Eryptosis}

\section{Introduction}

The 1,3-beta-glucan synthesis inhibitor Anidulafungin [1] is a relatively novel antifungal drug effective against a broad range of fungal infections [2-4], such as aspergillosis [5-15] and candidiasis [6-31]. The older commonly used antifungal drug amphotericin B [32] has previously been shown to trigger eryptosis $[33,34]$, the suicidal death of erythrocytes characterized by cell shrinkage [35] and cell membrane scrambling with phosphatidylserine translocation to the cell surface [36]. Mechanisms engaged in the stimulation of eryptosis include $\mathrm{Ca}^{2+}$ entry with increase of cytosolic $\mathrm{Ca}^{2+}$ activity $\left(\left[\mathrm{Ca}^{2+}\right]_{\mathrm{i}}\right)$ [36], ceramide [37], oxidative stress [36], energy depletion [36], caspases [36, 38, 39], as well as activation of several kinases including casein kinase $1 \alpha$, Janus-activated kinase JAK3, protein kinase $C$, and p38 kinase [36]. Eryptosis could further be triggered by inhibition of AMP activated kinase AMPK, cGMP-dependent protein kinase, PAK2 kinase and sorafenib/sunitinib sensitive kinases [36]. Cell membrane scrambling is further fostered by cell shrinkage [36].

Eryptosis is stimulated by a wide variety of small molecules [36, 40-70]. Eryptosis could be inhibited by nitric oxide (NO) [36].

The present study tested, whether Anidulafungin triggers eryptosis. To this end, human erythrocytes were exposed to Anidulafungin and phosphatidylserine surface abundance, cell volume, $\left[\mathrm{Ca}^{2+}\right]_{\mathrm{i}}$, abundance of reactive oxygen species (ROS) and ceramide determined by flow cytometry.

\section{Materials and Methods}

Erythrocytes, solutions and chemicals

Fresh Li-Heparin-anticoagulated blood samples were kindly provided by the blood bank of the University of Tübingen. The study is approved by the ethics committee of the University of Tübingen (184/2003 V). The blood was centrifuged at $120 \mathrm{~g}$ for $20 \mathrm{~min}$ at $21^{\circ} \mathrm{C}$ and the platelets and leukocytes-containing supernatant was disposed. Erythrocytes were incubated in vitro at a hematocrit of $0.4 \%$ in Ringer solution containing (in $\mathrm{mM}$ ) $125 \mathrm{NaCl}, 5 \mathrm{KCl}, 1 \mathrm{MgSO}_{4}, 32 \mathrm{~N}$-2-hydroxyethylpiperazine-N-2-ethanesulfonic acid (HEPES; pH 7.4), 5 glucose, $1 \mathrm{CaCl}_{2}$, at $37^{\circ} \mathrm{C}$ for 48 hours. Where indicated, erythrocytes were exposed for 48 hours to Anidulafungin (Selleckchem, Munich, Germany). To test for an involvement of oxidative stress, erythrocytes were exposed for 48 hours to a combination of Anidulafungin and the antioxidant N-acetylcysteine (Sigma Aldrich, Hamburg, Germany). To test for an involvement of protein kinase C or p38 kinase, erythrocytes were exposed for 48 hours to a combination of Anidulafungin and either PKC inhibitor staurosporine (Tocris bioscience, Bristol, UK) or p38 kinase inhibitor SB203580 (Tocris bioscience, Bristol, UK). In order to test, whether the casein kinase $1 \alpha$ is involved, erythrocytes were exposed for 48 hours to a combination of Anidulafungin and casein kinase $1 \alpha$ inhibitor D4476 (Sigma Aldrich, Hamburg, Germany). To test for an involvement of caspases, erythrocytes were exposed for 48 hours to a combination of Anidulafungin and pancaspase inhibitor zVAD (Enzo Life Sciences, Lörrach, Germany).

\section{Annexin-V-binding and forward scatter}

After incubation under the respective experimental condition, a $150 \mu \mathrm{l}$ cell suspension of erythrocytes was centrifuged at $1600 \mathrm{rpm}$ for $3 \mathrm{~min}$ and, after trashing the supernatant, the erythrocytes were stained with Annexin-V-FITC (1:200 dilution; ImmunoTools, Friesoythe, Germany) in this solution at $37^{\circ} \mathrm{C}$ for 15 min under protection from light. The annexin-V-abundance at the erythrocyte surface was subsequently determined on a FACS Calibur (BD, Heidelberg, Germany). Annexin-V-binding was measured with an excitation wavelength of $488 \mathrm{~nm}$ and an emission wavelength of $530 \mathrm{~nm}$. A marker (M1) was placed to set an arbitrary threshold between annexin-V-binding cells and control cells. The same threshold was used for untreated and Anidulafungin treated erythrocytes. A dot plot of forward scatter (FSC) vs. side scatter (SSC) was set to linear scale for both parameters. The threshold of forward scatter was set at the default value of “52”. 


\section{Cellular Physiology Cell Physiol Biochem 2016;38:2272-2284 and Biochemistry \begin{tabular}{l|l} 
DOI: 10.1159/000445582 & (c) 2016 The Author(s). Published by S. Karger AG, Basel \\
www.karger.com/cpb
\end{tabular} \\ Peter/Bissinger/Liu/Lang: Anidulafungin-Induced Eryptosis}

Intracellular $\mathrm{Ca}^{2+}$

After incubation, erythrocytes were washed in Ringer solution and then loaded with Fluo-3/AM (Biotium, Hayward, USA) in Ringer solution containing $5 \mathrm{mM} \mathrm{CaCl}_{2}$ and $5 \mu \mathrm{M}$ Fluo-3/AM. The cells were incubated at $37^{\circ} \mathrm{C}$ for $30 \mathrm{~min}$ and washed once in Ringer solution containing $5 \mathrm{mM} \mathrm{CaCl} \mathrm{Cl}_{2}$ The Fluo-3/ AM-loaded erythrocytes were resuspended in $200 \mu$ l Ringer solution. Then, $\mathrm{Ca}^{2+}$-dependent fluorescence intensity was measured in FL-1 with an excitation wavelength of $488 \mathrm{~nm}$ and an emission wavelength of $530 \mathrm{~nm}$ on a FACS Calibur. Afterwards, the geomean of the $\mathrm{Ca}^{2+}$ dependent fluorescence was determined.

Reactive oxygen species (ROS)

Oxidative stress was determined utilizing 2',7'-dichlorodihydrofluorescein diacetate (DCFDA). After incubation, a $150 \mu \mathrm{l}$ suspension of erythrocytes was washed in Ringer solution and then stained with DCFDA (Sigma Aldrich, Hamburg, Germany) in Ringer solution containing DCFDA at a final concentration of $10 \mu \mathrm{M}$. Erythrocytes were incubated at $37^{\circ} \mathrm{C}$ for $30 \mathrm{~min}$ in the dark and then washed two times in Ringer solution. The DCFDA-loaded erythrocytes were resuspended in $200 \mu$ l Ringer solution, and ROS-dependent fluorescence intensity was measured in FL-1 at an excitation wavelength of $488 \mathrm{~nm}$ and an emission wavelength of 530 $\mathrm{nm}$ on a FACS Calibur (BD). Subsequently, the geomean of the ROS-dependent fluorescence was determined

\section{Ceramide abundance}

To determine the ceramide abundance at the erythrocyte surface, a monoclonal antibody was used. After incubation, cells were stained for $1 \mathrm{~h}$ at $37^{\circ} \mathrm{C}$ with $1 \mu \mathrm{g} / \mathrm{ml}$ anti-ceramide antibody (clone MID 15B4; Alexis, Grünberg, Germany) in phosphate-buffered saline (PBS) containing $0.1 \%$ bovine serum albumin (BSA) at a dilution of 1:10. After two washing steps with PBS-BSA, cells were stained for 30 min with polyclonal fluorescein-isothiocyanate (FITC)-conjugated goat anti-mouse IgG and IgM specific antibody (BD Pharmingen, Hamburg, Germany) diluted 1:50 in PBS-BSA. Unbound secondary antibody was removed by repeated washing with PBS-BSA. Samples were then analyzed by flow cytometry in FL-1 at an excitation wavelength of $488 \mathrm{~nm}$ and an emission wavelength of $530 \mathrm{~nm}$. Finally, the geomean of the ceramide dependent fluorescence was determined.

\section{Statistics}

Data are expressed as arithmetic means \pm SEM. As indicated in the figure legends, statistical analysis was made using ANOVA with Tukey's test as post-test and $t$ test as appropriate. $\mathrm{n}$ denotes the number of different erythrocyte specimens studied. Since different erythrocyte specimens used in distinct experiments are differently susceptible to triggers of eryptosis, the same erythrocyte specimens have been used for control and experimental conditions.

\section{Results}

The present study explored whether Anidulafungin is able to trigger eryptosis, the suicidal erythrocyte death characterized by cell shrinkage and by phospholipid scrambling of the cell membrane with phosphatidylserine translocation to the cell surface. To this end, erythrocytes drawn from healthy volunteers were incubated for 48 hours in Ringer solution without or with Anidulafungin $(1.5-6 \mu \mathrm{g} / \mathrm{ml})$.

Erythrocyte volume was estimated from forward scatter, which was determined utilizing flow cytometry. As illustrated in Fig. 1, Anidulafungin $(1.5-6 \mu \mathrm{g} / \mathrm{ml})$ significantly decreased erythrocyte forward scatter. Moreover, Anidulafungin significantly increased the percentage of shrunken erythrocytes (Fig. 1C), an effect reaching statistical significance at $3 \mu \mathrm{g} / \mathrm{ml}$ Anidulafungin concentration. Anidulafungin treatment decreased the percentage of swollen erythrocytes (Fig. 1D), an effect reaching statistical significance at $1.5 \mu \mathrm{g} / \mathrm{ml}$ Anidulafungin concentration. The percentage of hemolytic erythrocytes was estimated from hemoglobin concentration in the supernatant. As illustrated in Fig. 2, a 48 hours exposure to Anidulafungin increased the percentage of hemolytic erythrocytes, an effect reaching statistical significance at $6 \mu \mathrm{g} / \mathrm{ml}$ Anidulafungin concentration. 


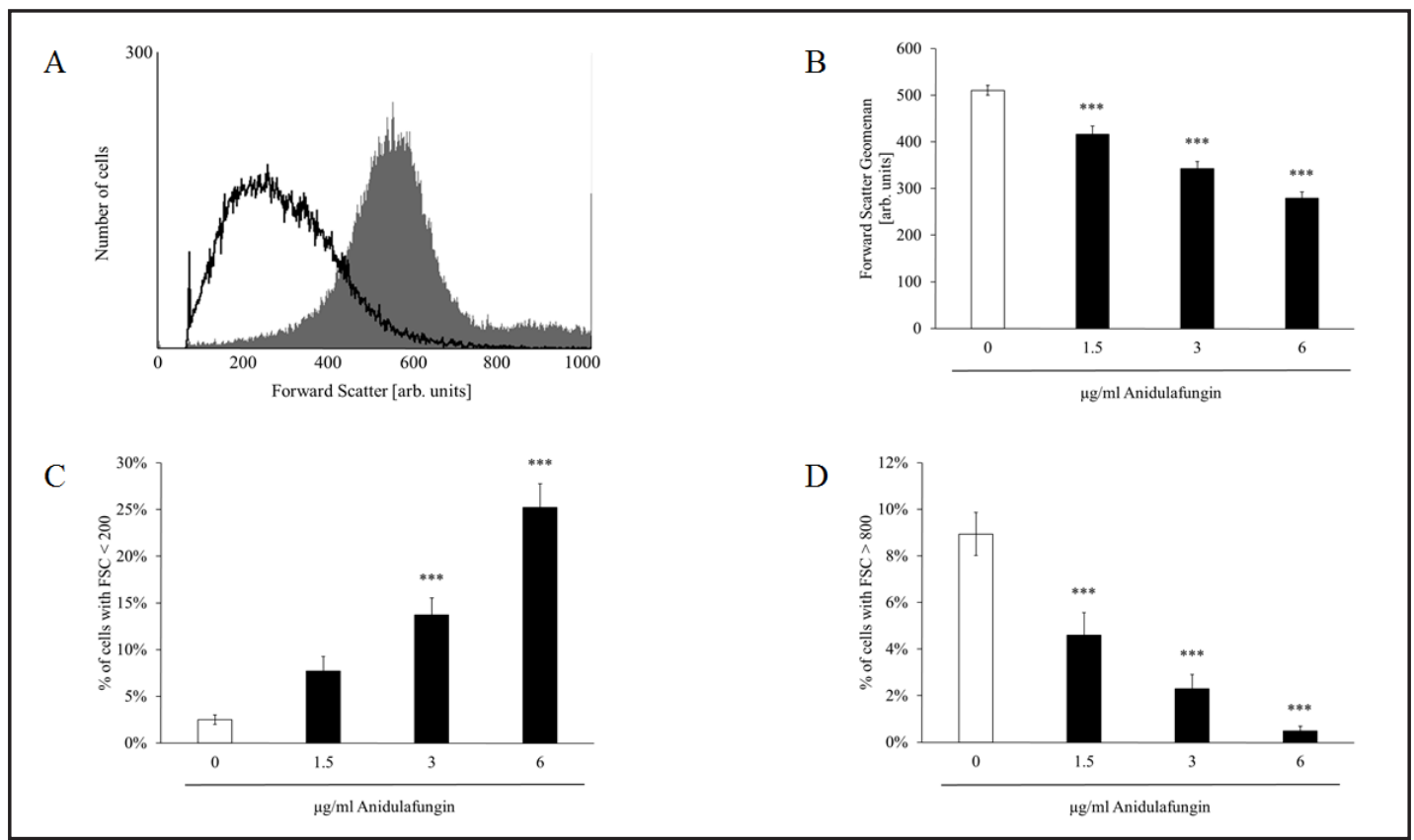

Fig. 1. Effect of Anidulafungin on erythrocyte forward scatter. (A) Original histogram of forward scatter of erythrocytes following exposure for 48 hours to Ringer solution without (grey area) and with (black line) presence of $6 \mu \mathrm{g} / \mathrm{ml}$ Anidulafungin. (B) Arithmetic means \pm SEM $(\mathrm{n}=12)$ of the erythrocyte forward scatter (FSC) following incubation for 48 hours to Ringer solution without (white bar) or with (black bars) Anidulafungin $(1.5-6 \mu \mathrm{g} / \mathrm{ml})$. (C) Arithmetic means \pm SEM $(\mathrm{n}=12)$ of the percentage of erythrocytes with forward scatter (FSC) $<200$ following incubation for 48 hours to Ringer solution without (white bar) or with (black bars) Anidulafungin $(1.5-6 \mu \mathrm{g} / \mathrm{ml})$. (D) Arithmetic means \pm SEM $(\mathrm{n}=12)$ of the percentage of erythrocytes with forward scatter (FSC) $>800$ following incubation for 48 hours to Ringer solution without (white bar) or with (black bars) Anidulafungin $(1.5-6 \mu \mathrm{g} / \mathrm{ml}) .{ }^{* * *}(\mathrm{p}<0.001)$ indicates significant difference from the absence of Anidulafungin (ANOVA).

Fig. 2. Effect of Anidulafungin on hemolysis. Arithmetic means \pm SEM $(n=8)$ of the percentage of hemolytic erythrocytes following incubation for 48 hours to Ringer solution without (white bar) or with (black bars) Anidulafungin $(1.5-6 \mu \mathrm{g} / \mathrm{ml}) .{ }^{* * *}(\mathrm{p}<0.001)$ indicates significant difference from the absence of Anidulafungin (ANOVA).

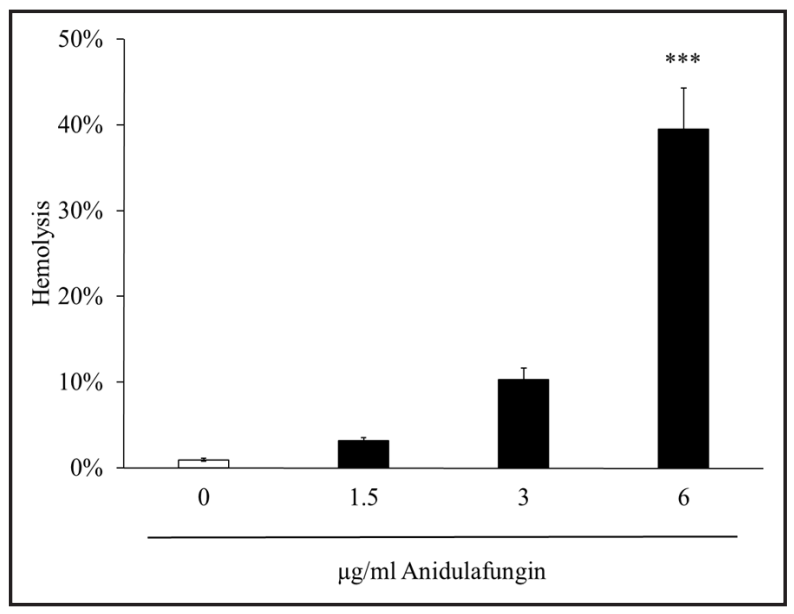

Phosphatidylserine exposing erythrocytes were identified utilizing annexin-V-binding, as determined by flow cytometry. As illustrated in Fig. 3, a 48 hours exposure to Anidulafungin increased the percentage of phosphatidylserine exposing erythrocytes, an effect reaching statistical significance at $3 \mu \mathrm{g} / \mathrm{ml}$ Anidulafungin concentration.

Fluo3 fluorescence was taken as a measure of cytosolic $\mathrm{Ca}^{2+}$ activity $\left(\left[\mathrm{Ca}^{2+}\right]_{\mathrm{i}}\right)$. As illustrated in Fig. 4, a 48 hours exposure to $6 \mu \mathrm{g} / \mathrm{ml}$ Anidulafungin significantly increased the Fluo3 fluorescence. 


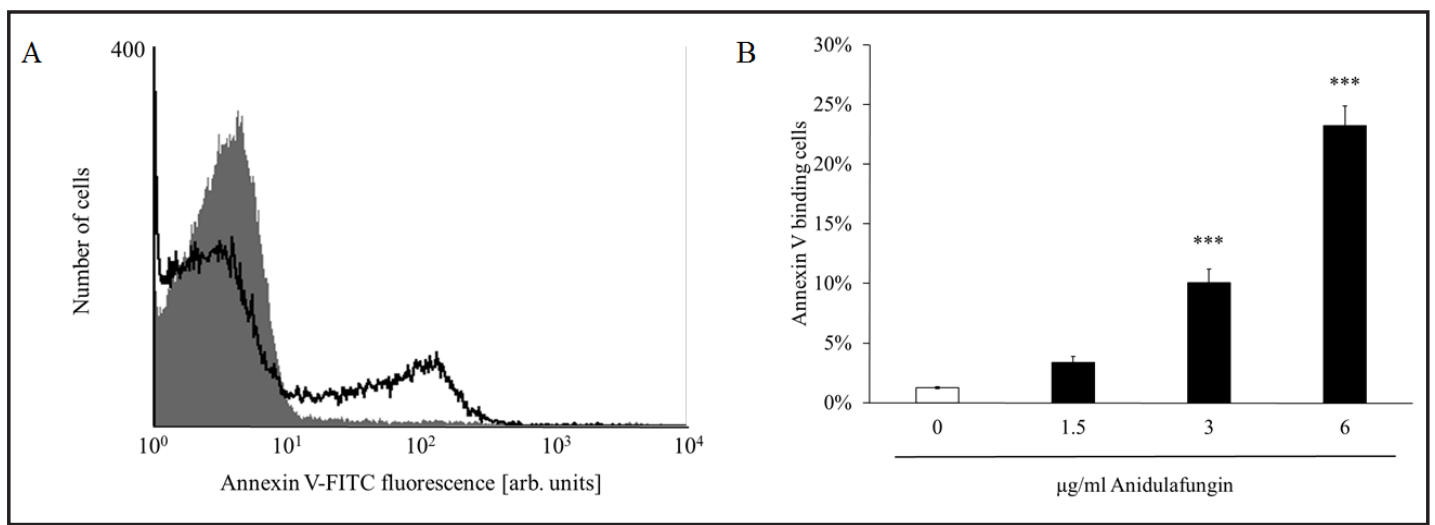

Fig. 3. Effect of Anidulafungin on phosphatidylserine exposure. (A) Original histogram of annexin-V-binding of erythrocytes following exposure for 48 hours to Ringer solution without (grey area) and with (black line) presence of $6 \mu \mathrm{g} / \mathrm{ml}$ Anidulafungin. (B) Arithmetic means \pm SEM ( $\mathrm{n}=12$ ) of erythrocyte annexin-V-binding following incubation for 48 hours to Ringer solution without (white bar) or with (black bars) Anidulafungin $(1.5-6 \mu \mathrm{g} / \mathrm{ml}) .{ }^{* * *}(\mathrm{p}<0.001)$ indicates significant difference from the absence of Anidulafungin (ANOVA).

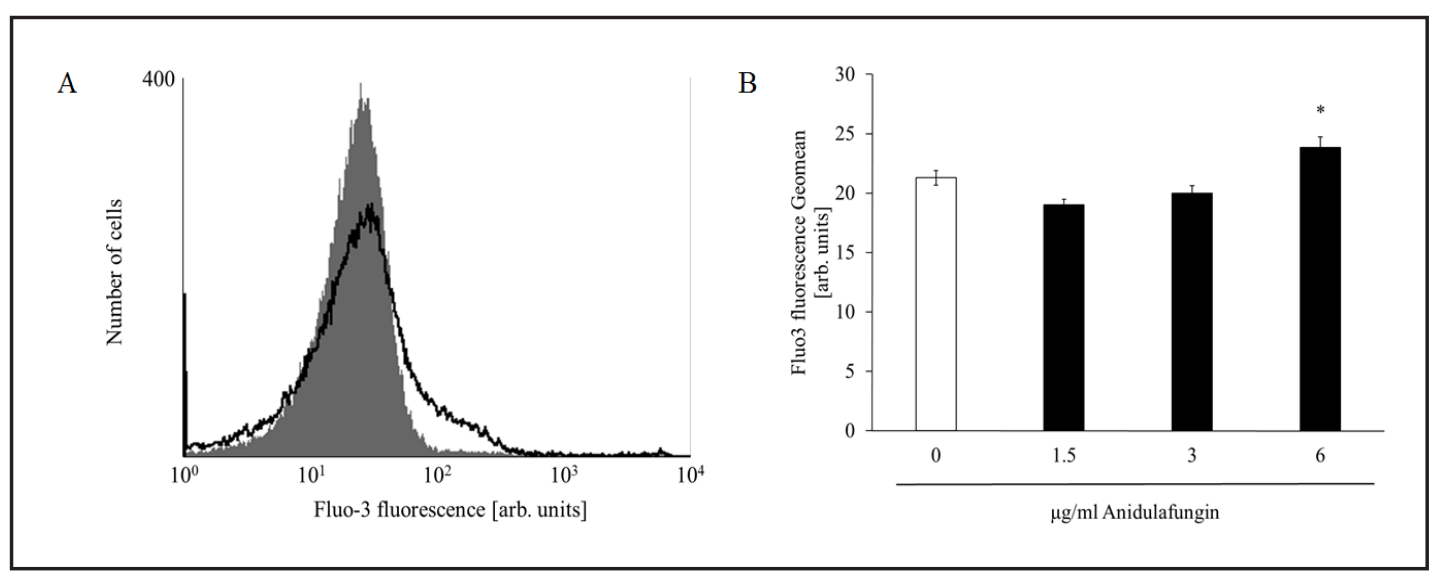

Fig. 4. Effect of Anidulafungin on cytosolic $\mathrm{Ca}^{2+}$ activity. (A) Original histogram of Fluo3 fluorescence in erythrocytes following exposure for 48 hours Ringer solution without (grey area) and with (black line) presence of $6 \mu \mathrm{g} / \mathrm{ml}$ Anidulafungin. (B) Arithmetic means \pm SEM $(n=12)$ of erythrocyte Fluo3 fluorescence following incubation for 48 hours to Ringer solution without (white bar) or with (black bars) Anidulafungin $(1.5-6 \mu \mathrm{g} / \mathrm{ml}) . *(\mathrm{p}<0.05)$ indicates significant difference from the absence of Anidulafungin (ANOVA).

A next series of experiments explored whether the Anidulafungin-induced translocation of phosphatidylserine was sensitive to extracellular $\mathrm{Ca}^{2+}$. To this end, erythrocytes were incubated for 48 hours in the absence or presence of $6 \mu \mathrm{g} / \mathrm{ml}$ Anidulafungin in the presence or nominal absence of extracellular $\mathrm{Ca}^{2+}$. As shown in Fig. 5, removal of extracellular $\mathrm{Ca}^{2+}$ slightly but significantly blunted the effect of Anidulafungin on the percentage of annexin-V-binding erythrocytes. However, even in the absence of extracellular $\mathrm{Ca}^{2+}$, Anidulafungin significantly increased the percentage of annexin-V-binding erythrocytes. Thus, Anidulafungin-induced cell shrinkage was in part, but not fully dependent on the presence of extracellular $\mathrm{Ca}^{2+}$.

Eryptosis is further stimulated by oxidative stress. Reactive oxygen species (ROS) was thus quantified utilizing $2^{\prime}, 7^{\prime}$-dichlorodihydrofluorescein diacetate (DCFDA). As a result, the DCFDA fluorescence was significantly $(\mathrm{p}<0.001)$ lower in the presence of $3 \mu \mathrm{g} / \mathrm{ml}$ Anidulafungin (11.02 \pm 0.29 a.u., $\mathrm{n}=8$ ) or $6 \mu \mathrm{g} / \mathrm{ml}$ Anidulafungin (12.11 \pm 0.69 a.u., $\mathrm{n}=8$ ) than in the absence of Anidulafungin (15.79 \pm 0.48 a.u., $n=8)$. Thus, Anidulafungin rather decreased oxidative stress. 


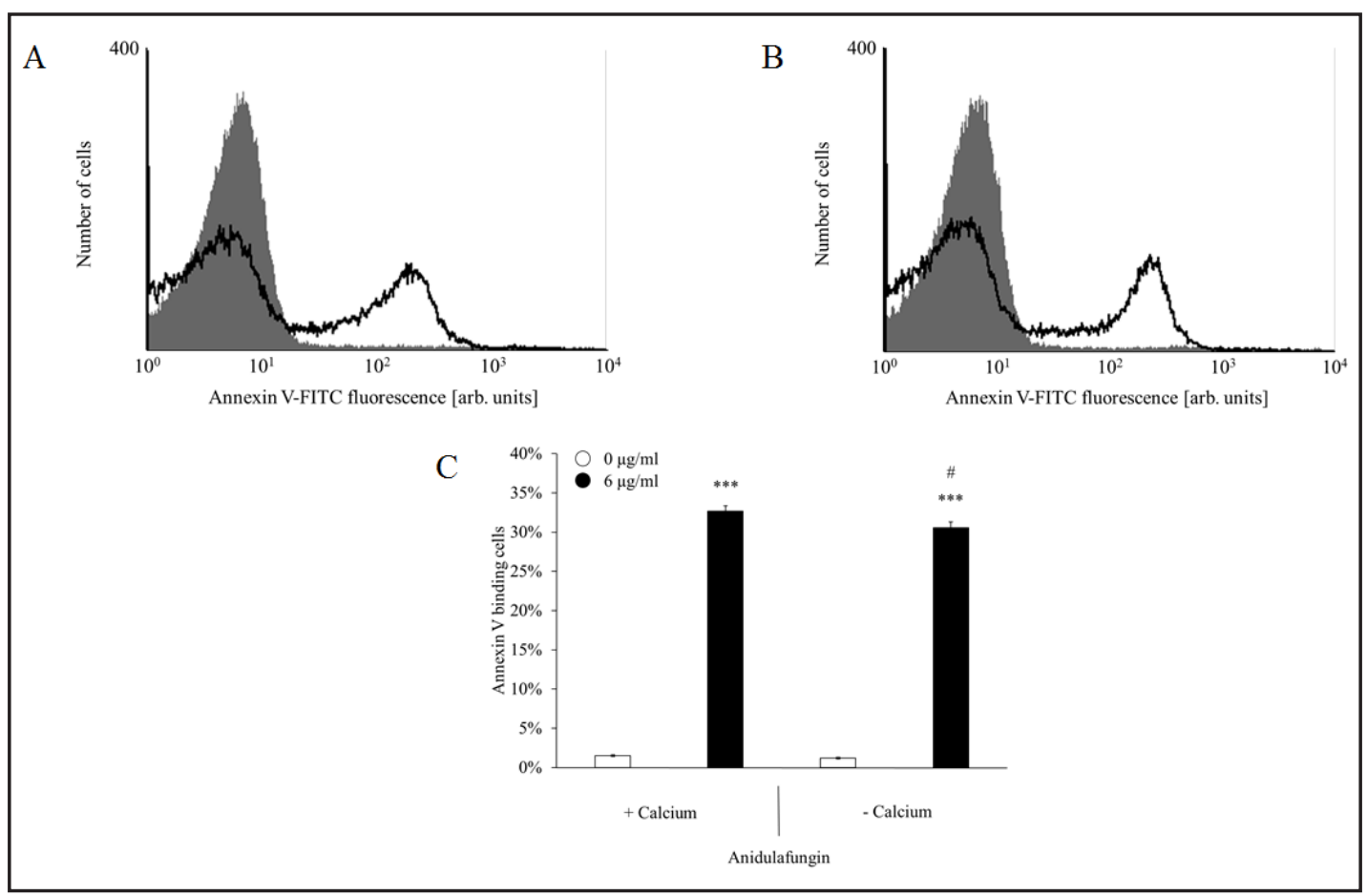

Fig. 5. $\mathrm{Ca}^{2+}$ sensitivity of Anidulafungin-induced phosphatidylserine exposure. A,B. Original histograms of annexin-V-binding of erythrocytes following exposure for 48 hours to Ringer solution without (grey areas) and with (black lines) Anidulafungin $(6 \mu \mathrm{g} / \mathrm{ml})$ in the presence (A) and absence (B) of extracellular $\mathrm{Ca}^{2+}$. (C) Arithmetic means \pm SEM ( $\mathrm{n}=11$ ) of annexin-V-binding of erythrocytes after a 48 hours treatment with Ringer solution without (white bars) or with (black bars) Anidulafungin $(6 \mu \mathrm{g} / \mathrm{ml})$ in the presence (left bars, + Calcium) and absence (right bars, - Calcium) of $\mathrm{Ca}^{2+}$. ${ }^{* * *}(\mathrm{p}<0.001)$ indicates significant difference from the absence of Anidulafungin, $\#(\mathrm{p}<0.05)$ indicates significant difference from the presence of $\mathrm{Ca}^{2+}(\mathrm{ANOVA})$.

To explore, whether the effect of Anidulafungin on cell membrane scrambling could be modified by the redox state, the influence of Anidulafungin on annexin-V-binding was tested in the absence or presence of the antioxidant $\mathrm{N}$-acetylcysteine $(1 \mathrm{mM})$. As a result, Anidulafungin $(6 \mu \mathrm{g} / \mathrm{ml})$ increased the percentage of phosphatidylserine exposing erythrocytes to similar values in the absence (from $2.04 \pm 0.42 \%$ to $15.66 \pm 0.94 \%, \mathrm{n}=8$ ) and in the presence (from $1.74 \pm 0.22 \%$ to $17.36 \pm 0.75 \%, \mathrm{n}=8$ ) of $\mathrm{N}$-acetylcysteine $(1 \mathrm{mM}$ ).

A further stimulator of eryptosis is ceramide. Ceramide abundance at the erythrocyte surface was thus quantified utilizing specific antibodies. As a result, the ceramide abundance was similar following exposure to $6 \mu \mathrm{g} / \mathrm{ml}$ Anidulafungin (15.25 \pm 2.17 a.u., $\mathrm{n}=5)$ and in the absence of Anidulafungin (15.65 \pm 0.35 a.u., $n=5$ ). Thus, Anidulafungin did not appreciably modify ceramide abundance.

To explore, whether the effects of Anidulafungin involved p38 kinase activity, the influence of Anidulafungin on annexin-V-binding was tested in the absence or presence of p38 kinase inhibitor SB203580 $(2 \mu \mathrm{M})$. As shown in Fig. 6, addition of SB203580 (2 $\mu \mathrm{M})$ significantly blunted the effect of Anidulafungin on the percentage of annexin-V-binding erythrocytes. However, even in the presence of SB203580, Anidulafungin significantly increased the percentage of annexin-V-binding erythrocytes. Thus, Anidulafungin-induced cell shrinkage was in part but not fully dependent on p38 kinase activity.

To explore, whether the effects of Anidulafungin involved protein kinase $C$, the influence of Anidulafungin on annexin-V-binding was tested in the absence or presence of protein kinase $\mathrm{C}$ inhibitor staurosporine $(1 \mu \mathrm{M})$. As a result, Anidulafungin $(6 \mu \mathrm{g} / \mathrm{ml})$ increased the percentage of phosphatidylserine exposing erythrocytes to similar values in the absence (from $3.03 \pm 0.79 \%$ to $30.98 \pm 1.16 \%, \mathrm{n}=8$ ) and in the presence (from $4.78 \pm 0.78 \%$ to $30.50 \pm 0.93 \%, \mathrm{n}=8)$ of staurosporine $(1 \mu \mathrm{M})$. 


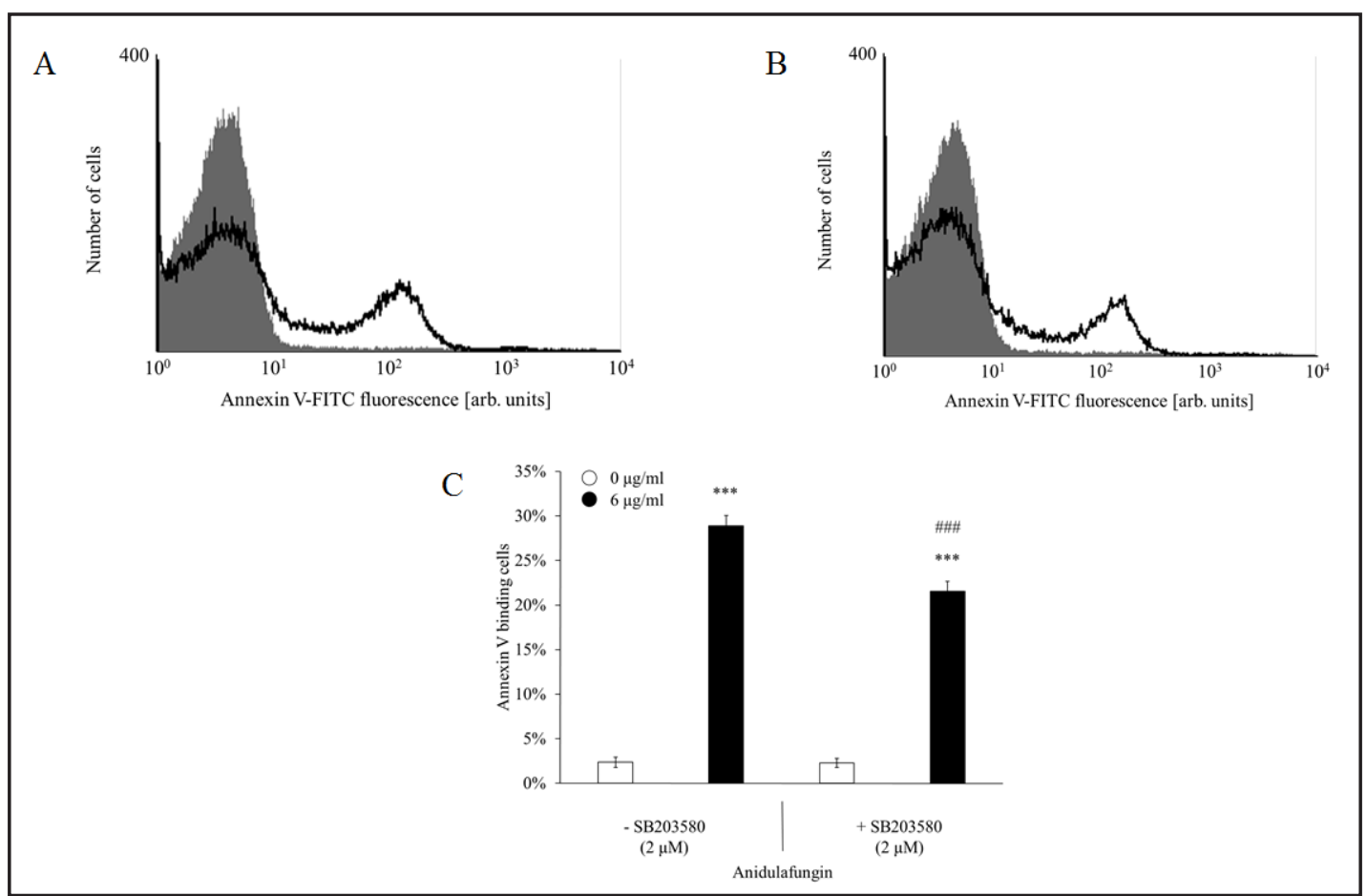

Fig. 6. SB203580 sensitivity of Anidulafungin-induced phosphatidylserine exposure. A,B. Original histograms of annexin-V-binding of erythrocytes following exposure for 48 hours to Ringer solution without (grey areas) and with (black line) Anidulafungin (6 $\mathrm{g} / \mathrm{ml}$ ) in the absence (A) and presence (B) of SB203580 $(2 \mu \mathrm{M})$. (C) Arithmetic means \pm SEM $(\mathrm{n}=8)$ of annexin-V-binding of erythrocytes after a 48 hours treatment with Ringer solution without (white bars) or with (black bars) Anidulafungin $(6 \mu \mathrm{g} / \mathrm{ml})$ in the absence (left bars) and presence (right bars) of $2 \mu \mathrm{M} \mathrm{SB203580.***}(\mathrm{p}<0.001)$ indicates significant difference from the absence of Anidulafungin, \#\#\#(p<0.001) indicates significant difference from the absence of $2 \mu \mathrm{M}$ SB203580 (ANOVA).

In order to test, whether the effects of Anidulafungin involved casein kinase $1 \alpha$, the influence of Anidulafungin on annexin-V-binding was tested in the absence or presence of casein kinase $1 \alpha$ inhibitor D4476 $(10 \mu \mathrm{M})$. As a result, Anidulafungin $(6 \mu \mathrm{g} / \mathrm{ml})$ increased the percentage of phosphatidylserine exposing erythrocytes to similar values in the absence (from $1.44 \pm 0.22 \%$ to $18.64 \pm 1.76 \%, \mathrm{n}=8$ ) and in the presence (from $1.58 \pm 0.12 \%$ to $20.20 \pm 1.88 \%, \mathrm{n}=8)$ of D4476 $(10 \mu \mathrm{M})$.

A further series of experiments addressed the putative involvement of caspases in Anidulafungin induced eryptosis. To this end, the influence of Anidulafungin on annexinV-binding was tested in the absence or presence of pancaspase inhibitor zVAD $(10 \mu \mathrm{M})$. As a result, Anidulafungin $(6 \mu \mathrm{g} / \mathrm{ml})$ increased the percentage of phosphatidylserine exposing erythrocytes to similar values in the absence (from $2.03 \pm 0.21 \%$ to $21.50 \pm 1.50 \%, \mathrm{n}=8$ ) and in the presence (from $2.10 \pm 0.24 \%$ to $23.27 \pm 1.77 \%, \mathrm{n}=8)$ of $\mathrm{zVAD}(10 \mu \mathrm{M})$.

Additional experiments addressed the sensitivity of Anidulafungin-induced cell membrane scrambling to nitric oxide. As illustrated in Fig. 7, addition of nitroprusside $(1 \mu \mathrm{M})$ slightly, but significantly blunted the effect of Anidulafungin on the percentage of annexinV-binding erythrocytes. However, even in the presence of nitroprusside, Anidulafungin significantly increased the percentage of annexin-V-binding erythrocytes.

A final series of experiments explored, whether the Anidulafungin-induced cell membrane scrambling was sensitive to increase of extracellular $\mathrm{K}^{+}$concentration and or cell volume. As shown in Fig. 8, an increase of extracellular $\mathrm{K}^{+}$concentration did not significantly modify the effect of Anidulafungin on the percentage of annexin-V-binding erythrocytes, even though it significantly blunted the effect of Anidulafungin on cell volume. 


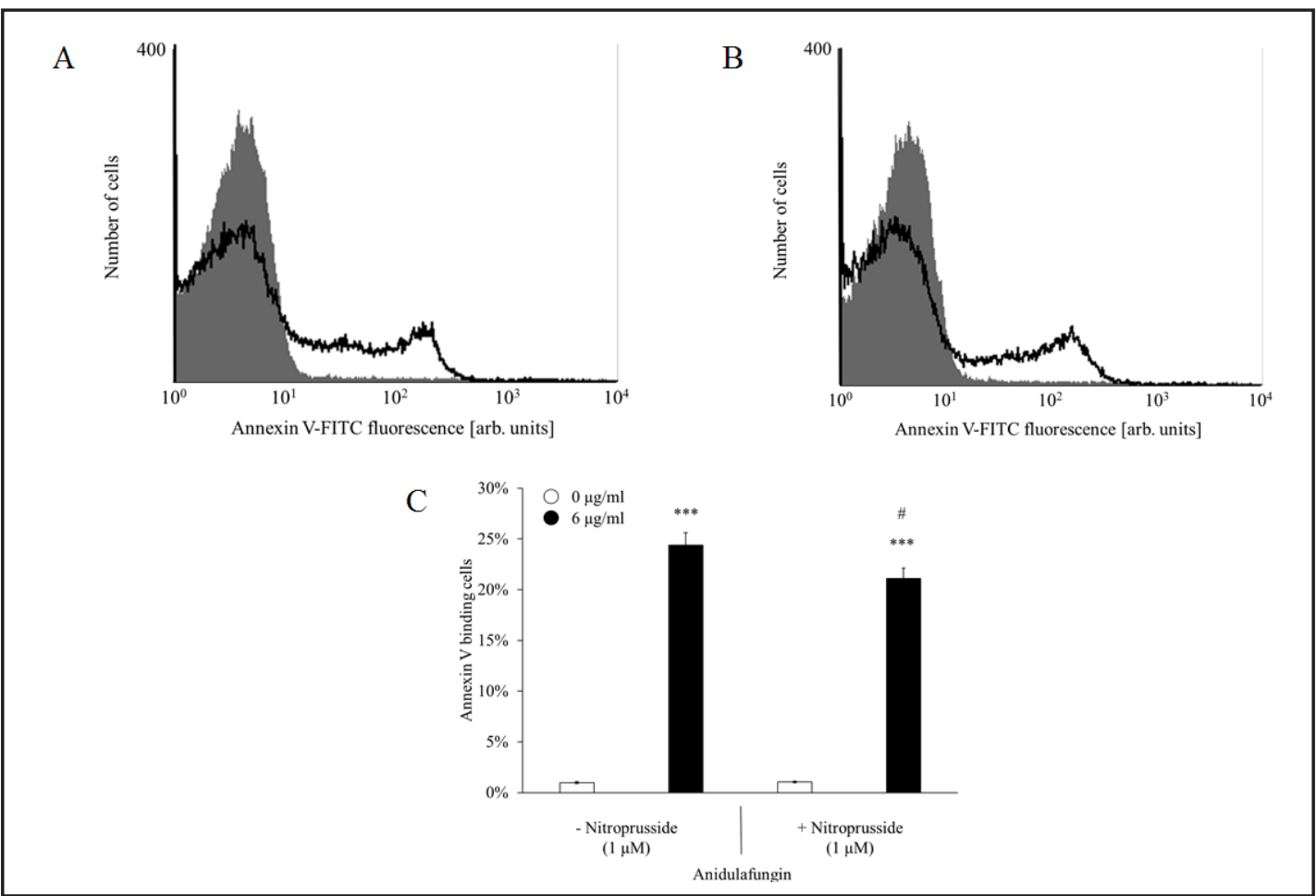

Fig. 7. Nitroprusside sensitivity of Anidulafungin-induced phosphatidylserine exposure. (A,B) Original histograms of annexin-V-binding of erythrocytes following exposure for 48 hours to Ringer solution without (grey areas) and with (black line) Anidulafungin $(6 \mu \mathrm{g} / \mathrm{ml})$ in the absence (A) and presence (B) of Nitroprusside $(1 \mu \mathrm{M})$. (C) Arithmetic means \pm SEM $(\mathrm{n}=8)$ of annexin-V-binding of erythrocytes after a 48 hours treatment with Ringer solution without (white bars) or with (black bars) Anidulafungin ( $6 \mu \mathrm{g} / \mathrm{ml}$ ) in the absence (left bars) and presence (right bars) of $1 \mu \mathrm{M}$ Nitroprusside. ${ }^{* * *}(\mathrm{p}<0.001)$ indicates significant difference from the absence of Anidulafungin, \# $(p<0.05)$ indicates significant difference from the absence of 1 $\mu \mathrm{M}$ Nitroprusside (ANOVA).

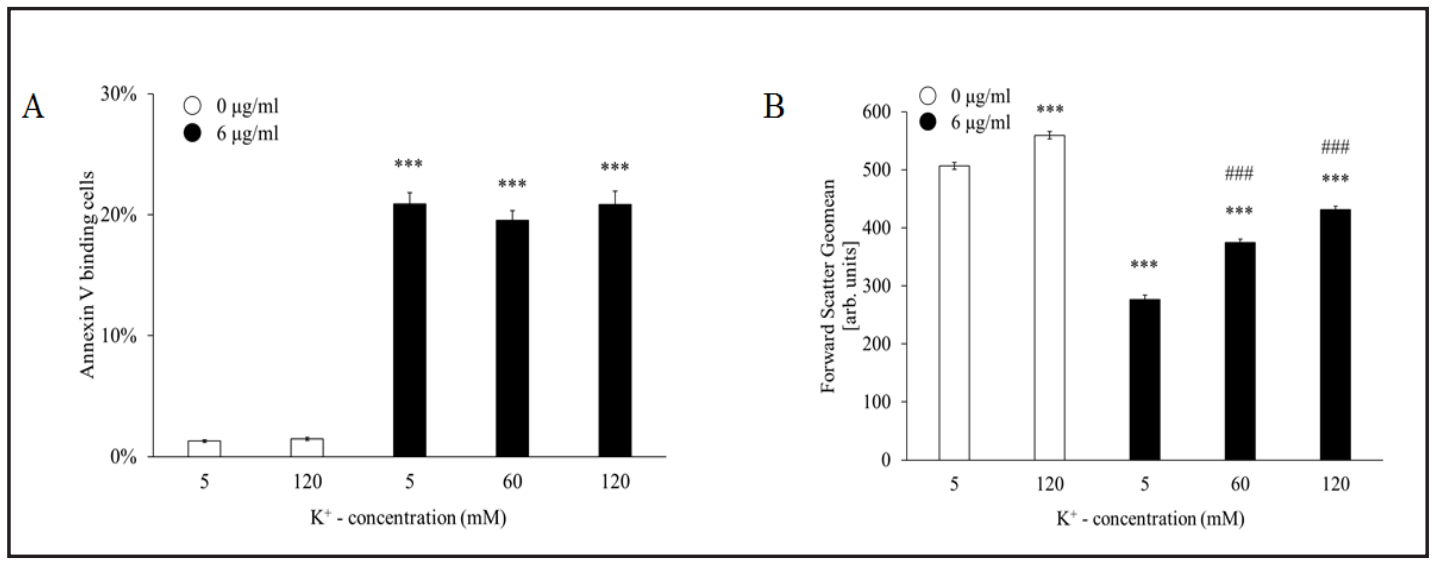

Fig. 8. Influence of extracellular $\mathrm{K}^{+}$concentration on annexin binding and forward scatter. (A) Arithmetic means \pm SEM $(n=20)$ of annexin-V-binding erythrocytes after a 48 hours treatment with Ringer solution without (white bars) or with (black bars) $6 \mu \mathrm{g} / \mathrm{ml}$ Anidulafungin at 5, 60 or $120 \mathrm{mM} \mathrm{K}^{+}$concentration. (B) Arithmetic means \pm SEM $(n=20)$ of forward scatter of erythrocytes after a 48 hours treatment with Ringer solution without (white bars) or with (black bars) $6 \mu \mathrm{g} / \mathrm{ml}$ Anidulafungin at 5, 60 or $120 \mathrm{mM} \mathrm{K}^{+}$concentration. ${ }^{* * *}(\mathrm{p}<0.001)$ indicates significant difference from the absence of Anidulafungin, $\# \# \#(\mathrm{p}<0.001)$ indicates significant difference from the respective value at $5 \mathrm{mM} \mathrm{K}^{+}$(ANOVA). 


\section{Cellular Physiology Cell Physiol Biochem 2016;38:2272-2284 \\ and Biochemistry Published online: May 23, $2016 \quad \begin{aligned} & \text { DOI: 10.1159/000445582 } \\ & \begin{array}{l}\text { c } 2016 \text { The Author(s). Published by S. Karger AG, Basel } \\ \text { ww.karger.com/cpb }\end{array}\end{aligned}$ \\ Peter/Bissinger/Liu/Lang: Anidulafungin-Induced Eryptosis}

\section{Discussion}

The present observations disclose a novel effect of Anidulafungin, i.e. the stimulation of eryptosis, the suicidal erythrocyte death. A 48 hours exposure of erythrocytes from healthy individuals to Anidulafungin resulted in cell shrinkage and cell membrane scrambling with phosphatidylserine translocation to the erythrocyte surface. The concentrations required for this effect were well in the range of peak plasma concentrations determined in Anidulafungin treated patients [71]. The sensitivity to Anidulafungin induced eryptosis is presumably enhanced in clinical conditions with accelerated eryptosis, such as dehydration [72], hyperphosphatemia [73], chronic kidney disease (CKD) [74-77], hemolytic-uremic syndrome [78], diabetes [79], hepatic failure [80], malignancy [36], sepsis [81], sickle-cell disease [36], beta-thalassemia [36], Hb-C and G6PD-deficiency [36], as well as Wilsons disease [82].

The signaling of Anidulafungin on erythrocyte cell membrane scrambling apparently involves to some extent $\mathrm{Ca}^{2+}$ entry, as Anidulafungin slightly, but significantly inceased Fluo3-fluorescence and the effect of Anidulafungin on annexin-V-binding was slightly, but significantly blunted by removal of extracellular $\mathrm{Ca}^{2+}$. Moreover, the effect of Anidulafungin on annexin-V-binding was significantly blunted by the $\mathrm{p} 38$ kinase inhibitor SB203580, pointing to a contribution of p38 kinase to the stimulation of cell membrane scrambling. The effect of Anidulafungin on cell membrane scrambling did not involve oxidative stress, as the drug rather decreased DCFDA fluorescence and the effect of Anidulafungin on annexin-V-binding was not significantly blunted by the antioxidant $\mathrm{N}$-acetylcysteine. Moreover, the effect of Anidulafungin on annexin-V-binding was not paralleled by increase of ceramide abundance and was not significantly blunted by PKC inhibitor staurosporine, casein kinase $1 \alpha$ inhibitor D4476 or pancaspase inhibitor zVAD. The effect of Anidulafungin on annexin-V-binding was further insensitive to increase of extracellular $\mathrm{K}^{+}$concentration, which significantly blunted Anidulafungin-induced cell shrinkage. The effect of Anidulafungin on annexin-V-binding was, however, significantly blunted in the presence of NO donor nitroprusside.

Besides its effect on eryptosis, Anidulafungin triggered hemolysis. Anidulafungin has previously been shown to trigger hemolysis [83]. The main physiological function of eryptosis is the clearance of defective erythrocytes from circulating blood prior to hemolysis [36]. If not preceded by eryptosis, hemolysis leads to release of hemoglobin, which passes the renal glomerular filter, precipitates in the acidic lumen of renal tubules, occludes nephrons and thus triggers renal failure [84]. In malaria, eryptosis accomplishes removal of infected erythocytes from circulating blood [36]. Accordingly, stimulation of eryptosis by the antifungal drug amphotericin B [33] has previously been shown to counteract the development of parasitemia and thus to favourably influence the clinical course of malaria [34]. It is tempting to speculate that Anidulafungin may have a similar positive effect in malaria.

Due to rapid clearance of eryptotic erythrocytes from circulating blood [36], excessive eryptosis may lead to anemia. However, enhanced eryptosis triggers anemia only, if the accelerated loss of erythrocytes outcasts the formation of new erythrocytes [36]. Phosphatidylserine exposing erythrocytes further adhere to the vascular wall [85], stimulate blood clotting and thus foster thrombosis [86-88]. Enhanced eryptosis may thus impair microcirculation [37, 86, 89-92].

In conclusion, Anidulafungin triggers eryptosis with cell shrinkage and cell membrane scrambling, and triggers hemolysis. The effect on cell membrane srambling is accomplished in part by $\mathrm{Ca}^{2+}$ entry and activation of p38 kinase.

\section{Acknowledgements}

The authors acknowledge the meticulous preparation of the manuscript by Tanja Loch. The study was supported by the Deutsche Forschungsgemeinschaft and Open Access Publishing Fund of Tuebingen University. 


\section{Cellular Physiology Cell Physiol Biochem 2016;38:2272-2284 and Biochemistry Published online: May 23, $2016 \quad \begin{aligned} & \text { DOI: 10.1159/000445582 } \\ & \begin{array}{l}\text { C 2016 The Author(s). Published by S. Karger AG, Basel } \\ \text { www.karger.com/cpb }\end{array}\end{aligned}$ \\ Peter/Bissinger/Liu/Lang: Anidulafungin-Induced Eryptosis}

\section{Disclosure Statement}

The authors of this manuscript state that they have no conflicts of interest to declare.

\section{References}

1 Martin-Mazuelos E: Anidulafungin Vicuron. IDrugs 2003;6:980-986.

2 Wilke MH: Invasive fungal infections in infants-focus on anidulafungin. Clin Med Insights Pediatr 2013;7:711.

3 Perkhofer S, Lass-Florl C: Anidulafungin and voriconazole in invasive fungal disease: pharmacological data and their use in combination. Expert Opin Investig Drugs 2009;18:1393-1404.

$4 \quad$ Vazquez JA: The safety of anidulafungin. Expert Opin Drug Saf 2006;5:751-758.

5 Liu P, Mould DR: Population pharmacokinetic analysis of voriconazole and anidulafungin in adult patients with invasive aspergillosis. Antimicrob Agents Chemother 2014;58:4718-4726.

6 George J, Reboli AC: Anidulafungin: when and how? The clinician's view. Mycoses 2012;55:36-44.

7 Hinske LC, Weis F, Heyn J, Hinske P, Beiras-Fernandez A: The role of micafungin and anidulafungin in the treatment of systemic fungal infections: applications and patents for two novel echinocandins. Recent Pat Antiinfect Drug Discov 2012;7:1-7.

8 Kuti EL, Kuti JL: Pharmacokinetics, antifungal activity and clinical efficacy of anidulafungin in the treatment of fungal infections. Expert Opin Drug Metab Toxicol 2010;6:1287-1300.

9 Menichetti F: Anidulafungin, a new echinocandin: effectiveness and tolerability. Drugs 2009;69 Suppl 1:9597.

10 Morace G, Borghi E, Iatta R, Montagna MT: Anidulafungin, a new echinocandin: in vitro activity. Drugs 2009;69 Suppl 1:91-94.

11 Scheinfeld N: A review of the new antifungals: posaconazole, micafungin, and anidulafungin. J Drugs Dermatol 2007;6:1249-1251.

12 Vehreschild JJ, Kummerle T, Karthaus M, Cornely OA: Anidulafungin--state of affairs from a clinical perspective. Mycoses 2007;50 Suppl 1:38-43.

13 Espinel-Ingroff A: In vitro antifungal activities of anidulafungin and micafungin, licensed agents and the investigational triazole posaconazole as determined by NCCLS methods for 12,052 fungal isolates: review of the literature. Rev Iberoam Micol 2003;20:121-136.

14 Raasch RH: Anidulafungin: review of a new echinocandin antifungal agent. Expert Rev Anti Infect Ther 2004;2:499-508.

15 Vazquez JA, Sobel JD: Anidulafungin: a novel echinocandin. Clin Infect Dis 2006;43:215-222.

16 Glockner A: Treatment and prophylaxis of invasive candidiasis with anidulafungin, caspofungin and micafungin:review of the literature. Eur J Med Res 2011;16:167-179.

17 Kofla G, Ruhnke M: Pharmacology and metabolism of anidulafungin, caspofungin and micafungin in the treatment of invasive candidosis: review of the literature. Eur J Med Res 2011;16:159-166.

18 Mayr A, Aigner M, Lass-Florl C: Anidulafungin for the treatment of invasive candidiasis. Clin Microbiol Infect 2011;17 Suppl 1:1-12.

19 Tapisiz A: Anidulafungin: is it a promising option in the treatment of pediatric invasive fungal infections? Expert Rev Anti Infect Ther 2011;9:339-346.

20 Wilke M: Treatment and prophylaxis of invasive candidiasis with anidulafungin, caspofungin and micafungin and its impact on use and costs: review of the literature. Eur J Med Res 2011;16:180-186.

21 de la Torre P, Meyer DK, Reboli AC: Anidulafungin: a novel echinocandin for candida infections. Future Microbiol 2008;3:593-601.

22 Estes KE, Penzak SR, Calis KA, Walsh TJ: Pharmacology and antifungal properties of anidulafungin, a new echinocandin. Pharmacotherapy 2009;29:17-30.

23 Joseph JM, Kim R, Reboli AC: Anidulafungin: a drug evaluation of a new echinocandin. Expert Opin Pharmacother 2008;9:2339-2348.

24 Kett DH, Cubillos GF: Anidulafungin in the treatment of patients with invasive candidiasis. Int J Antimicrob Agents 2008;32 Suppl 2:S99-S102. 


\section{Cellular Physiology Cell Physiol Biochem 2016;38:2272-2284 \begin{tabular}{l|l} 
and Biochemistry & DOI: 10.1159/000445582 \\
Published online: May 23, 2016 & $\begin{array}{l}\text { C } 2016 \text { The Author(s). Published by S. Karger AG, Basel } \\
\text { www.karger.com/cpb }\end{array}$
\end{tabular} \\ Peter/Bissinger/Liu/Lang: Anidulafungin-Induced Eryptosis}

25 Davis SL, Vazquez JA: Anidulafungin: an evidence-based review of its use in invasive fungal infections. Core Evid 2008;2:241-249.

26 Anidulafungin: ECB, LY 303366, V-echinocandin, VEC, VER 002, VER-02. Drugs R D 2003;4:167-173.

27 Cohen-Wolkowiez M, Benjamin DK Jr, Steinbach WJ, Smith PB: Anidulafungin: a new echinocandin for the treatment of fungal infections. Drugs Today (Barc) 2006;42:533-544.

28 de la Torre P, Reboli AC: Anidulafungin: a new echinocandin for candidal infections. Expert Rev Anti Infect Ther 2007;5:45-52.

29 Krause DS, Reinhardt J, Vazquez JA, Reboli A, Goldstein BP, Wible M, Henkel T, Anidulafungin Invasive Candidiasis Study G: Phase 2, randomized, dose-ranging study evaluating the safety and efficacy of anidulafungin in invasive candidiasis and candidemia. Antimicrob Agents Chemother 2004;48:2021-2024.

30 Pfaller MA: Anidulafungin: an echinocandin antifungal. Expert Opin Investig Drugs 2004;13:1183-1197.

31 Vazquez JA: Anidulafungin: a new echinocandin with a novel profile. Clin Ther 2005;27:657-673.

32 Mazzei T, Novelli A: Pharmacological properties of antifungal drugs with a focus on anidulafungin. Drugs 2009;69 Suppl 1:79-90.

33 Mahmud H, Mauro D, Qadri SM, Foller M, Lang F: Triggering of suicidal erythrocyte death by amphotericin B. Cell Physiol Biochem 2009;24:263-270.

34 Siraskar B, Ballal A, Bobbala D, Foller M, Lang F: Effect of amphotericin B on parasitemia and survival of plasmodium berghei-infected mice. Cell Physiol Biochem 2010;26:347-354.

35 Lang PA, Kaiser S, Myssina S, Wieder T, Lang F, Huber SM: Role of Ca2+-activated K+ channels in human erythrocyte apoptosis. Am J Physiol Cell Physiol 2003;285:C1553-C1560.

36 Lang E, Lang F: Mechanisms and pathophysiological significance of eryptosis, the suicidal erythrocyte death. Semin Cell Dev Biol 2015;39:35-42.

37 Abed M, Towhid ST, Mia S, Pakladok T, Alesutan I, Borst O, Gawaz M, Gulbins E, Lang F: Sphingomyelinaseinduced adhesion of eryptotic erythrocytes to endothelial cells. Am J Physiol Cell Physiol 2012;303:C991999.

38 Lau IP, Chen H, Wang J, Ong HC, Leung KC, Ho HP, Kong SK: In vitro effect of CTAB- and PEG-coated gold nanorods on the induction of eryptosis/erythroptosis in human erythrocytes. Nanotoxicology 2012;6:847856.

39 Maellaro E, Leoncini S, Moretti D, Del Bello B, Tanganelli I, De Felice C, Ciccoli L: Erythrocyte caspase-3 activation and oxidative imbalance in erythrocytes and in plasma of type 2 diabetic patients. Acta Diabetol 2013;50:489-495.

40 Alzoubi K, Calabròa S, Bissinger R, Abed M, Faggio C, Lang F: Stimulation of Suicidal Erythrocyte Death by Artesunate. Cell Physiol Biochem 2014;34:2232-2244.

41 Alzoubi K, Egler J, Abed M, Lang F: Enhanced Eryptosis Following Auranofin Exposure. Cell Physiol Biochem 2015;37:1018-1028.

42 Arnold M, Bissinger R, Lang F: Mitoxantrone-induced suicidal erythrocyte death. Cell Physiol Biochem 2014;34:1756-1767.

43 Arnold M, Lang E, Modicano P, Bissinger R, Faggio C, Abed M, Lang F: Effect of nitazoxanide on erythrocytes. Basic Clin Pharmacol Toxicol 2014;114:421-426.

44 Bissinger R, Barking S, Alzoubi K, Liu G, Liu G, Lang F: Stimulation of Suicidal Erythrocyte Death by the Antimalarial Drug Mefloquine. Cell Physiol Biochem 2015;36:1395-1405.

45 Bissinger R, Bouguerra G, Stockinger K, Abbes S, Lang F: Triggering of Suicidal Erythrocyte Death by Topotecan. Cell Physiol Biochem 2015;37:1607-1618.

46 Bissinger R, Fischer S, Jilani K, Lang F: Stimulation of Erythrocyte Death by Phloretin. Cell Physiol Biochem 2014;34:2256-2265.

47 Bissinger R, Lupescu A, Zelenak C, Jilani K, Lang F: Stimulation of eryptosis by cryptotanshinone. Cell Physiol Biochem 2014;34:432-442.

48 Bouguerra G, Aljanadi O, Bissinger R, Abbes S, Lang F: Embelin-Induced Phosphatidylserine Translocation in the Erythrocyte Cell Membrane. Cell Physiol Biochem 2015;37:1629-1640.

49 Bouguerra G, Bissinger R, Abbes S, Lang F: Stimulation of Eryptosis by Narasin. Cell Physiol Biochem 2015;37:1807-1816.

50 Bouguerra G, Bissinger R, Abbes S, Lang F: Zopolrestat Induced Suicidal Death of Human Erythrocytes. Cell Physiol Biochem 2015;37:1537-1546. 


\section{Cellular Physiology Cell Physiol Biochem 2016;38:2272-2284 \begin{tabular}{l|l} 
and Biochemistry & DOI: 10.1159/000445582 \\
Published online: May 23, 2016 & $\begin{array}{l}\text { C } 2016 \text { The Author(s). Published by S. Karger AG, Basel } \\
\text { www.karger.com/cpb }\end{array}$
\end{tabular} \\ Peter/Bissinger/Liu/Lang: Anidulafungin-Induced Eryptosis}

51 Briglia M, Fazio A, Faggio C, Laufer S, Alzoubi K, Lang F: Triggering of Suicidal Erythrocyte Death by Ruxolitinib. Cell Physiol Biochem 2015;37:768-778.

52 Briglia M, Fazio A, Signoretto E, Faggio C, Lang F: Edelfosine Induced Suicidal Death of Human Erythrocytes. Cell Physiol Biochem 2015;37:2221-2230.

53 Calabro S, Alzoubi K, Faggio C, Laufer S, Lang F: Triggering of Suicidal Erythrocyte Death Following Boswellic Acid Exposure. Cell Physiol Biochem 2015;37:131-142.

54 Egler J, Lang F: Licochalcone A Induced Suicidal Death of Human Erythrocytes. Cell Physiol Biochem 2015;37:2060-2070.

55 Faggio C, Alzoubi K, Calabro S, Lang F: Stimulation of suicidal erythrocyte death by PRIMA-1. Cell Physiol Biochem 2015;35:529-540.

56 Fazio A, Briglia M, Faggio C, Alzoubi K, Lang F: Stimulation of Suicidal Erythrocyte Death by Garcinol. Cell Physiol Biochem 2015;37:805-815.

57 Jacobi J, Lang E, Bissinger R, Frauenfeld L, Modicano P, Faggio C, Abed M, Lang F: Stimulation of erythrocyte cell membrane scrambling by mitotane. Cell Physiol Biochem 2014;33:1516-1526.

58 Lang E, Jilani K, Bissinger R, Rexhepaj R, Zelenak C, Lupescu A, Lang F, Qadri SM: Vitamin D-Rich Diet in Mice Modulates Erythrocyte Survival. Kidney Blood Press Res 2015;40:403-412.

59 Lang E, Zelenak C, Eberhard M, Bissinger R, Rotte A, Ghashghaeinia M, Lupescu A, Lang F, Qadri SM: Impact of Cyclin-Dependent Kinase CDK4 Inhibition on Eryptosis. Cell Physiol Biochem 2015;37:1178-1186.

60 Lupescu A, Bissinger R, Goebel T, Salker MS, Alzoubi K, Liu G, Chirigiu L, Mack AF, Qadri SM, Lang F: Enhanced suicidal erythrocyte death contributing to anemia in the elderly. Cell Physiol Biochem 2015;36:773-783.

61 Lupescu A, Bissinger R, Herrmann T, Oswald G, Jilani K, Lang F: Induction of suicidal erythrocyte death by novobiocin. Cell Physiol Biochem 2014;33:670-680.

62 Lupescu A, Bissinger R, Warsi J, Jilani K, Lang F: Stimulation of erythrocyte cell membrane scrambling by gedunin. Cell Physiol Biochem 2014;33:1838-1848.

63 Malik A, Bissinger R, Calabro S, Faggio C, Jilani K, Lang F: Aristolochic Acid Induced Suicidal Erythrocyte Death. Kidney Blood Press Res 2014;39:408-419.

64 Officioso A, Alzoubi K, Manna C, Lang F: Clofazimine Induced Suicidal Death of Human Erythrocytes. Cell Physiol Biochem 2015;37:331-341.

65 Oswald G, Alzoubi K, Abed M, Lang F: Stimulation of suicidal erythrocyte death by ribavirin. Basic Clin Pharmacol Toxicol 2014;114:311-317.

66 Peter T, Bissinger R, Enkel S, Alzoubi K, Oswald G, Lang F: Programmed erythrocyte death following in vitro Treosulfan treatment. Cell Physiol Biochem 2015;35:1372-1380.

67 Stockinger K, Bissinger R, Bouguerra G, Abbes S, Lang F: Enhanced Eryptosis Following Exposure to Carnosic Acid. Cell Physiol Biochem 2015;37:1779-1791.

68 Tesoriere L, Attanzio A, Allegra M, Cilla A, Gentile C, Livrea MA: Oxysterol mixture in hypercholesterolemiarelevant proportion causes oxidative stress-dependent eryptosis. Cell Physiol Biochem 2014;34:10751089.

69 Waibel S, Bissinger R, Bouguerra G, Abbes S, Lang F: Saquinavir Induced Suicidal Death of Human Erythrocytes. Cell Physiol Biochem 2015;37:1973-1982.

70 Zierle J, Bissinger R, Egler J, Lang F: Lapatinib Induced Suicidal Death of Human Erythrocytes. Cell Physiol Biochem 2015;37:2275-2287.

71 Liu P, Ruhnke M, Meersseman W, Paiva JA, Kantecki M, Damle B: Pharmacokinetics of anidulafungin in critically ill patients with candidemia/invasive candidiasis. Antimicrob Agents Chemother 2013;57:16721676.

72 Abed M, Feger M, Alzoubi K, Pakladok T, Frauenfeld L, Geiger C, Towhid ST, Lang F: Sensitization of erythrocytes to suicidal erythrocyte death following water deprivation. Kidney Blood Press Res 2013;37:567-578.

73 Voelkl J, Alzoubi K, Mamar AK, Ahmed MS, Abed M, Lang F: Stimulation of suicidal erythrocyte death by increased extracellular phosphate concentrations. Kidney Blood Press Res 2013;38:42-51.

74 Abed M, Artunc F, Alzoubi K, Honisch S, Baumann D, Foller M, Lang F: Suicidal erythrocyte death in endstage renal disease. J Mol Med (Berl) 2014;92:871-879.

75 Ahmed MS, Langer H, Abed M, Voelkl J, Lang F: The uremic toxin acrolein promotes suicidal erythrocyte death. Kidney Blood Press Res 2013;37:158-167. 


\section{Cellular Physiology Cell Physiol Biochem 2016;38:2272-2284 \begin{tabular}{l|l} 
DOI: 10.1159/000445582 & $\begin{array}{l}\text { O 2016 The Author(s). Published by S. Karger AG, Basel } \\
\text { www.karger.com/cpb }\end{array}$
\end{tabular} \\ Peter/Bissinger/Liu/Lang: Anidulafungin-Induced Eryptosis}

76 Polak-Jonkisz D, Purzyc L: $\mathrm{Ca}(2+)$ influx versus efflux during eryptosis in uremic erythrocytes. Blood Purif 2012;34:209-210; author reply 210.

77 Calderon-Salinas JV, Munoz-Reyes EG, Guerrero-Romero JF, Rodriguez-Moran M, Bracho-Riquelme RL, Carrera-Gracia MA, Quintanar-Escorza MA: Eryptosis and oxidative damage in type 2 diabetic mellitus patients with chronic kidney disease. Mol Cell Biochem 2011;357:171-179.

78 Lang PA, Beringer O, Nicolay JP, Amon O, Kempe DS, Hermle T, Attanasio P, Akel A, Schafer R, Friedrich B, Risler T, Baur M, Olbricht CJ, Zimmerhackl LB, Zipfel PF, Wieder T, Lang F: Suicidal death of erythrocytes in recurrent hemolytic uremic syndrome. J Mol Med (Berl) 2006;84:378-388.

79 Nicolay JP, Schneider J, Niemoeller OM, Artunc F, Portero-Otin M, Haik G, Jr., Thornalley PJ, Schleicher E, Wieder T, Lang F: Stimulation of suicidal erythrocyte death by methylglyoxal. Cell Physiol Biochem 2006;18:223-232.

80 Lang E, Gatidis S, Freise NF, Bock H, Kubitz R, Lauermann C, Orth HM, Klindt C, Schuier M, Keitel V, Reich M, Liu G, Schmidt S, Xu HC, Qadri SM, Herebian D, Pandyra AA, Mayatepek E, Gulbins E, Lang F, Haussinger D, Lang KS, Foller M, Lang PA: Conjugated bilirubin triggers anemia by inducing erythrocyte death. Hepatology 2015;61:275-284.

81 Kempe DS, Akel A, Lang PA, Hermle T, Biswas R, Muresanu J, Friedrich B, Dreischer P, Wolz C, Schumacher U, Peschel A, Gotz F, Doring G, Wieder T, Gulbins E, Lang F: Suicidal erythrocyte death in sepsis. J Mol Med (Berl) 2007;85:273-281.

82 Lang PA, Schenck M, Nicolay JP, Becker JU, Kempe DS, Lupescu A, Koka S, Eisele K, Klarl BA, Rubben H, Schmid KW, Mann K, Hildenbrand S, Hefter H, Huber SM, Wieder T, Erhardt A, Haussinger D, Gulbins E, Lang F: Liver cell death and anemia in Wilson disease involve acid sphingomyelinase and ceramide. Nat Med 2007;13:164-170.

83 Denning DW: Echinocandin antifungal drugs. Lancet 2003;362:1142-1151.

84 Harrison HE, Bunting H, Ordway NK, Albrink WS: The Pathogenesis of the Renal Injury Produced in the Dog by Hemoglobin or Methemoglobin. J Exp Med 1947;86:339-356.

85 Borst O, Abed M, Alesutan I, Towhid ST, Qadri SM, Foller M, Gawaz M, Lang F: Dynamic adhesion of eryptotic erythrocytes to endothelial cells via CXCL16/SR-PSOX. Am J Physiol Cell Physiol 2012;302:C644-C651.

86 Andrews DA, Low PS: Role of red blood cells in thrombosis. Curr Opin Hematol 1999;6:76-82.

87 Chung SM, Bae ON, Lim KM, Noh JY, Lee MY, Jung YS, Chung JH: Lysophosphatidic acid induces thrombogenic activity through phosphatidylserine exposure and procoagulant microvesicle generation in human erythrocytes. Arterioscler Thromb Vasc Biol 2007;27:414-421.

88 Zwaal RF, Comfurius P, Bevers EM: Surface exposure of phosphatidylserine in pathological cells. Cell Mol Life Sci 2005;62:971-988.

89 Closse C, Dachary-Prigent J, Boisseau MR: Phosphatidylserine-related adhesion of human erythrocytes to vascular endothelium. Br J Haematol 1999;107:300-302.

90 Gallagher PG, Chang SH, Rettig MP, Neely JE, Hillery CA, Smith BD, Low PS: Altered erythrocyte endothelial adherence and membrane phospholipid asymmetry in hereditary hydrocytosis. Blood 2003;101:46254627.

91 Pandolfi A, Di Pietro N, Sirolli V, Giardinelli A, Di Silvestre S, Amoroso L, Di Tomo P, Capani F, Consoli A, Bonomini M: Mechanisms of uremic erythrocyte-induced adhesion of human monocytes to cultured endothelial cells. J Cell Physiol 2007;213:699-709.

92 Wood BL, Gibson DF, Tait JF: Increased erythrocyte phosphatidylserine exposure in sickle cell disease: flowcytometric measurement and clinical associations. Blood 1996;88:1873-1880. 